\title{
KUALITAS AIR HUJAN \\ DAN FAKTOR LINGKUNGAN YANG MEMPENGARUHINYA
}

\author{
Oleh: Sudarmaji
}

\begin{abstract}
$\overline{\text { ABSTRACT }}$
Rain water constitutes the input to the hydrology system looking at its quality, compared with the other natural water, is represents the purest water by mean of its composition nearly close to H2O. However, it is naturally never found rain water which is truly composed with only H2O. In the big towns various environment factors have influenced the quality of rain water. Pollution on air is caused by gas exile as well as the emiton of motor vehicles. And gas exile from the factory has polluted the rain water in the urban area. Rain water at the beach is also influenced by the ocean activity and its water composition. In the volcanic area the rain water is also influenced by the volcanic activity. Each of the environment above mentioned influences the composition of rain water. The study, which is concerning with the quality of rain water, utilizes the observation yield recorded by previous observer in Java; however the yield of abroad observation is also utilized for comparation.
\end{abstract}

\section{$\overline{\text { INTISARI }}$}

Hujan merupakan masukan dalam sistem hidrologi. Ditinjau dari kualitasnya dibandingkan dengan air alami lainnya, air hujan merupakan air paling murni dalam arti komposisinya hampir mendekati H2O. Namun demikian, pada hakekatnya tidak pernah dijumpai air hujan yang betul-betul hanya tersusun atas H2O saja, berbagai faktor lingkungan telah mempengaruhi kualitas air hujan tersebut. Pencemaran udara yang terjadi di kota-kota besar, baik yang berupa buangan gas maupun emisi dari kendaraan bermotor. Serta buangan gas dari pabrik telah mempengaruhi kualitas air hujan yang jatuh didaerah kota. Air hujan di daerah pantai juga terpengaruh oleh laut dengan segala aktifitas dan komposisi airnya. Didaerah gunung api yang masih aktif air hujan juga dipengaruhi oleh aktifitas tersebut. Masing-masing lingkungan tersebut diatas mempengaruhi komposisi air hujan. Kajian kualitas air hujan dilakukan dengan mengambil hasil penelitian yang dilakukan oleh peneliti sebelumnya di daerah pulau Jawa, namun demikian hasil penelitian yang dilakukan di luar negeri juga digunakan sebagai pembanding. 


\section{PENDAHULUAN}

Dalam sistem hidrologi hujan merupakan salah satu bentuk masukan ke dalam DAS untuk dapat menghasilkan keluaran yang berupa aliran, baik aliran air permukaan maupun airtanah. Hujan dengan berbagai macam sifat nya (tebal, intensitas dan durasinya) menentukan output yang dihasilkannya, yang biasanya tercermin dalam bentuk hidrograf aliran. Selain itu hujan dalam rantai siklus hidrologi terbentuk karena proses penguapan air laut diikuti dengan terbentuknya titik-titik air hujan karena karena proses kondensasi. Setelah persyaratan memenuhi, maka titik-titik air hujan tersebut jatuh sebagi hujan. Dalam proses terbentuknya titik-titik air hujan diperlukan inti kondensasi untuk mengikat uap air agar membentuk partikel yang besar. Inti kondensasi tersebut dapat berupa butiran debu meteorik maupun debu lain yang sangat kecil. Dengan demikian dalam proses ini sudah masuk zat dari luar, yang menyebabkan air tidak lagi mempunyai komposisi sebagai $\mathrm{H} 2 \mathrm{O}$ murni. Dalam proses jatuhnya, ke permukaan bumi titik-titik air hujan melalui lapisan udara yang terdiri oleh berbagai macam gas, antara lain adalah $\mathrm{O} 2$ dan $\mathrm{CO} 2$ dan gas-gas lain. Oleh karena itu sudah barang tentu apabila gas-gas tersebut sebagian terlarut dalam air. Karena itulah maka air hujan mengan- dung berbagai macam gas di dalamnya.

Aktivitas manusia dalam seharihari menghasilkan berbagai macam limbah, baik limbah yang berasal dari kegiatan sehari-hari berupa limbah domestik, maupun limbah dari kegiatan industri, pertambangan dan pertanian. Bentuk limbah tersebut dapat berupa padat, cair maupun gas. Limbah dalam bentuk gas akan dibuang ke atmosfer, dan dengan bantuan angin, baik arah maupun kecepatannya maka limbah yang berbentuk gas tersebut akan dibawa ketempat yang jauh dari sumbernya.

Air hujan yang jauh di suatu tempat dapat melarutkan gas-gas tersebut, sehingga pencemaran udara dapat mempengaruhi kualitas air hujan yang jatuh di suatu wilayah. Tulisan ini bermaksud untuk mengungkap kuali tas air hujan yang di berbagai kota untuk melihat pengaruh pencemaran udara terhadap kualitas air hujan.

\section{DATA DAN METODA}

Dalam penelitian ini digunakan data hasil pengamatan yang dilakukan oleh peneliti sebelumnya. Data yang digunakan adalah data oleh Setianingsih (1989), Sudarmadji $(1975,1986)$ dan Sudarmadji (1995). Sebagi perbandingan digunakan hasil pengamatan Badan Meteorologi dan Geofisika yang diterbitkan dalam Kualitas Lingkungan di Indonesia 1990 serta tulisan 


\begin{tabular}{lllll}
\hline \multicolumn{4}{l}{ Tabel 1. Karakteristik Air Hujan diJakarta, Medan dan Manado } \\
\hline Parameter & & Jakarta & Medan & Manado \\
pH & & 5,58 & 5,78 & 5,78 \\
$\mathrm{SO} 4$ & $(\mathrm{mg} / 1)$ & 0,04 & 0,12 & 0,04 \\
$\mathrm{NO} 3$ & $(\mathrm{mg} / 1)$ & 1,66 & 0,88 & 0,61 \\
$\mathrm{NH} 3$ & $(\mathrm{mg} / \mathrm{l})$ & 1,42 & 0,20 & 0,28 \\
\hline
\end{tabular}

Sumber : Kantor Menteri KLH, 1990.

dari Appelo (1986). Data dari beberapa laporan penelitian juga diambil, walaupun penelitian tersebut bukan merupakan semata-mata penelitian kualitas air hujan. Dalam penelitian ini ditekankan kepada hasil penelitian yang dilakukan di beberapa daerah Pulau Jawa, namun demikian hasil penelitian yang didapat di luar negeri digunakan sebagai pembanding.

\section{HASIL PENELITIAN}

\section{a. Kualitas Air Hujan di} Daerah Perkotaan

Dari berbagai penelitian yang di lakukan dapat diketahu bahwa kualitas air hujan di berbagai macam kota di dunia ternyata sangat bervariasi, namun demikian kota-kota yang termasuk kedalam kota yang mempunyai

Tabel 2. Analisis Air Hujan di Beberapa Kota (dalam umoles/1)

\begin{tabular}{|c|c|c|c|c|c|c|}
\hline \multirow{2}{*}{ Parameter } & $\begin{array}{c}\text { Kiruna } \\
\text { Swedia } \\
\text { 55-'57 }\end{array}$ & $\begin{array}{c}\text { Hubbard } \\
\text { Brook, US } \\
\text { '63-'74 }\end{array}$ & $\begin{array}{c}\text { De Kooy } \\
\text { Netherl } \\
\text { '78-'83 }\end{array}$ & $\begin{array}{c}\text { Beek } \\
\text { Netherl } \\
\text { '78-83 }\end{array}$ & $\begin{array}{c}\text { Thumba } \\
\text { India } \\
1975\end{array}$ & $\begin{array}{c}\text { Delhi } \\
\text { India } \\
1975\end{array}$ \\
\hline $\mathrm{pH}$ & 5,6 & 4,1 & 4,40 & 4,75 & - & - \\
$\mathrm{Na}$ & 13 & 5 & 302 & 43 & 200 & 30 \\
$\mathrm{~K}$ & 5 & 2 & 9 & 7 & 6 & 7 \\
$\mathrm{Mg}$ & 5 & 2 & 35 & 9 & 19 & 4 \\
$\mathrm{Ca}$ & 16 & 4 & 19 & 47 & 23 & 29 \\
$\mathrm{NH}$ & 6 & 12 & 78 & 128 & - & - \\
$\mathrm{C} 1$ & 11 & 7 & 379 & 54 & 229 & 28 \\
$\mathrm{SO}_{4}$ & 21 & 30 & 66 & 87 & 7 & 4 \\
$\mathrm{NO}_{3}$ & 5 & 12 & 63 & 63 & - & - \\
$\mathrm{HCO}_{3}$ & 21 & - & - & 9 & - & - \\
\hline
\end{tabular}

Sumber : Appelø, 1986 
industri besar serta mempunyai ke padatan lalu lintas yang tinggi menunjukkan kualitas air hujan yang lebih buruk dibandingkan dengan kota-kota yang masih sedikit kegiatannya. Beberapa kota di Indonesia berdasarkan penelitian ternyata mempunyai kecenderungan yang sama (Tabel 1). Kadar $\mathrm{NO}_{3}$ dalam air hujan cukup tinggi, namun demikian kadar $\mathrm{SO}_{4}$ di kota-kota di Eropa, Amerika Serikat dan India memiliki kadar zat kimia yang cukup berarti pula. Nampak jelas terlihat bahwa kota yang terletak di dekat pantai memiliki kadar klorida yang tinggi.

Di kota Yogyakarta, yang merupakan kota wisata dengan ukuran lebih kecil dari Surabaya maupun Jakarta telah dilakukan penelitian terhadap air

Tabel 3. Analisis Air Hujan di Yogyakarta

\begin{tabular}{|c|c|c|c|c|c|}
\hline Parameter & $\begin{array}{c}\text { Bronto } \\
\text { kusuman } \\
\text { Yk - } 1989\end{array}$ & $\begin{array}{l}\text { Condong } \\
\text { Catur } \\
\text { Yk-1989 }\end{array}$ & $\begin{array}{c}\text { Sapen } \\
1986\end{array}$ & $\begin{array}{c}\text { Gondo } \\
\text { manan } \\
1986\end{array}$ & $\begin{array}{c}\text { Ngampilan } \\
1986\end{array}$ \\
\hline DHL & 98,36 & 21,21 & 11,2 & 13,1 & 23,2 \\
\hline $\mathrm{mhos} / \mathrm{cm}$ & 6,01 & 6,4 & 7,4 & 7,4 & 7,2 \\
\hline $\mathrm{pH}$ & 0,01 & 0,01 & - & - & - \\
\hline $\mathrm{Na} \quad \mathrm{mg} / \mathrm{l}$ & 0,001 & 0,001 & - & - & - \\
\hline $\mathrm{K} \quad \mathrm{mg} / 1$ & 0,49 & 0,47 & 1,42 & 2,04 & 1,33 \\
\hline $\mathrm{Ca} \quad \mathrm{mg} / 1$ & 0,10 & 0,11 & 1,26 & 1,35 & 1,00 \\
\hline $\mathrm{Mg} \quad \mathrm{mg} / 1$ & 0,11 & 0,11 & 1,33 & 1,59 & 1,32 \\
\hline $\mathrm{Cl} \quad \mathrm{mg} / 1$ & 0,08 & 0,10 & 0,08 & 0,06 & 0,10 \\
\hline $\mathrm{SO} 4 \mathrm{mg} / 1$ & 0,04 & 0,02 & 0,075 & 0,185 & 0,133 \\
\hline NO3 mg/ & 12,04 & 22,41 & 20,69 & - & - \\
\hline $\begin{array}{l}\mathrm{HCO} 3 \mathrm{mg} / 1 \\
\mathrm{CO}_{2} \quad \mathrm{mg} / 1\end{array}$ & 9,12 & 7,60 & 6,1 & 7,1 & 6,6 \\
\hline
\end{tabular}

Sumber: 1. Setianingsih (1989)

2. Sudarmadji (1986)

masih tergolong rendah. $\mathrm{PH}$ air hujan sudah menunjukkan sifat yang asam $(7,0)$.

Appelo (1986) memperlihatkan hasil pengamatannya dari berbagai penelitian seperti tercantum dalam tabel 2. Dalam arah yang hampir sama dapat diketahui bahwa air hujan yang jatuh hujan, bahkan tidak hanya di dalam kota, namun juga termasuk daerahdaerah di luar kota sekitarnya. Hasil penelitian yang dilakukan Sudarmadji (1986) dan Asma Irma Setianingsih (1989) ditunjukan pada tabel 3. 
Terlihat bahwa kualitas air hujan yang jatuh di pusat kota cenderung mempunyai kadar $\mathrm{CO}_{2}$ yang tinggi. Di Yogyakarta pengamayan didalam kota menunjukkan angka $\mathrm{CO} 2$ yang tinggi bagi air hujan yang jatuh didalam kota, masing-masing sebesar 9,12 dan $7,60 \mathrm{mg} / 1$ di daerah Brontokusuman dan Catur Tunggal di Yogyakarta. Dalam daerah yang oleh Sudarmadji (1986) telah teramati bahwa $\mathrm{CO} 2$ di dalam kota berkisar antara $6,1 \mathrm{mg} / 1$ sampai $7,7 \mathrm{mg} / 1$ yang teramati di tiga lokasi. Apabila dibandingkan dengan penelitian yang nilai $\mathrm{pH}$, dimana di kota di Eropa sudah memiliki $\mathrm{pH}$ yang kurang dari 6,0, namun di kota-kota di Indonesia masih mempunyai $\mathrm{pH}$ yang lebih besar dari 5,0 bahkan mendekati nilai 7,0. Kadar parameter kimia yang lain juga lebih tinggi dibandingkan dengan yang didapat di Indonesia. Walaupun angka dinyatakan dalam $\mu$ moles $/ 1$, namun bila dikonversikan ke dalam $\mathrm{mg} / \mathrm{l}$ angka kadar parameter zat kimia juga tetap lebih tinggi.

\section{b. Kualitas Air Hujan di Luar kota}

Tabel 4. Kualitas Air Hujan di Luar Kota

\begin{tabular}{|ll|c|c|c|}
\hline \multicolumn{2}{|c|}{ Parameter } & Siluk & Godean (1974) & $\begin{array}{c}\text { Kalijarut } \\
\text { Hutan Pinus }\end{array}$ \\
\hline $\mathrm{DHL}$ & $\mathrm{mhos} / \mathrm{cm}$ & 28,2 & 37,27 & 16,3 \\
$\mathrm{pH}$ & & 6,61 & 6,01 & 5,95 \\
$\mathrm{Na}$ & $\mathrm{mg} / 1$ & 0,03 & 0,01 & - \\
$\mathrm{K}$ & $\mathrm{mg} / 1$ & 0,002 & 0,00 & - \\
$\mathrm{Ca}$ & $\mathrm{mg} / 1$ & 0,48 & 0,40 & 2,0 \\
$\mathrm{Mg}$ & $\mathrm{mg} / 1$ & 0,21 & 0,19 & 0,35 \\
$\mathrm{C} 1$ & $\mathrm{mg} / 1$ & 0,17 & 0,11 & 6,56 \\
$\mathrm{SO} 4$ & $\mathrm{mg} / 1$ & 0,08 & 0,10 & 7,0 \\
$\mathrm{NO} 3$ & $\mathrm{mg} / 1$ & 0,04 & 0,01 & 0,0 \\
$\mathrm{HCO} 3$ & $\mathrm{mg} / 1$ & 0,50 & 0,60 & 23,33 \\
$\mathrm{CO} 2$ & $\mathrm{mg} / 1$ & 3,04 & 3,04 & 6,0 \\
\hline
\end{tabular}

Sumber : 1. Setianingsih (1989)

\section{Sudarmadji (1995)}

dilakukan di luar negeri, nampak bahwa kualitas air hujan di kota-kota di Indonesia masih memiliki kualitas yang lebth baik. Sebagai contoh adalah
Air hujan yang dikumpulkan di daerah luar kota sudah cenderung mempunyai kadar pencemar yang lebih rendah dibandingkan dengan 
Tabel 5. Kualitas Air Hujan di Daerah Pantai dst.

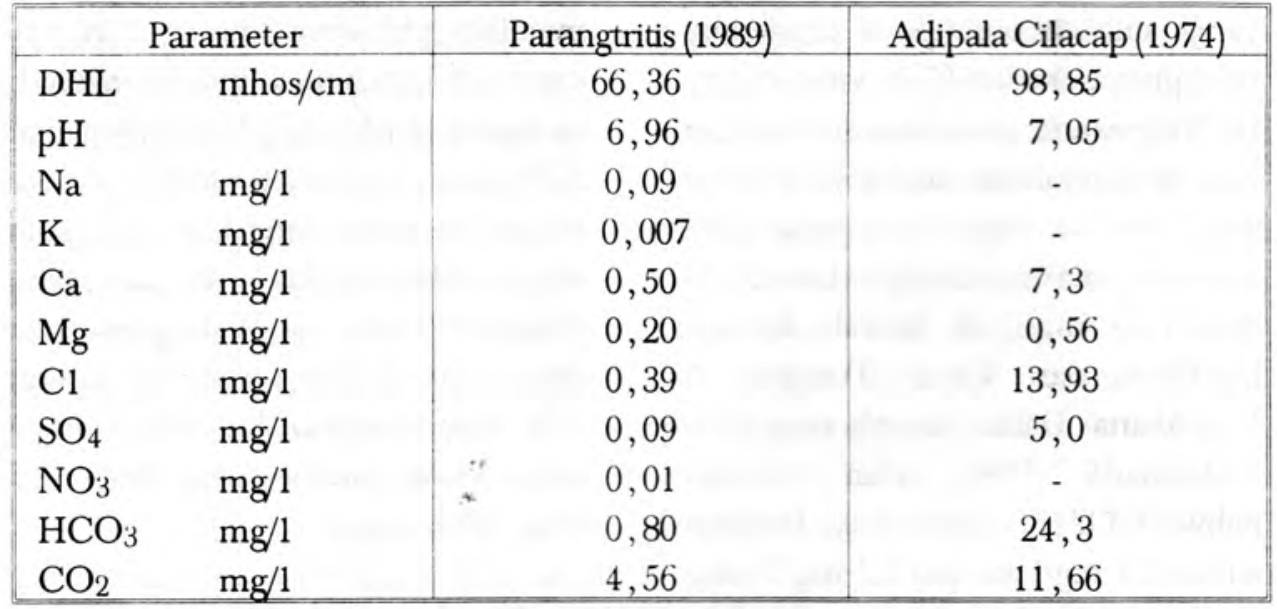

Sumber : 1. Setianingsih (1989)

2. Sudarmadji (1995)

kadarnya dengan air hujan yang jatuh tidak memiliki industri yang memdi daerah kota. Tentu saja yang dimaksudkan adalah daerah luar kota yang buang limbah gas. Beberapa sampel air hujan yang mencerminkan keadaan

Tabel 6. Kualitas Air Hujan di Daerah Pantai dst.

\begin{tabular}{|lc|r|r|c|}
\hline & Parameter & Pakem & Plawangan & Baturraden \\
\hline $\mathrm{DHL}$ & $\mathrm{mhos} / \mathrm{cm}$ & 91,65 & 68,71 & - \\
$\mathrm{pH}$ & & 6,74 & 6,12 & 6,4 \\
$\mathrm{Na}$ & $\mathrm{mg} / 1$ & 0,00 & 0,00 & - \\
$\mathrm{K}$ & $\mathrm{mg} / 1$ & 0,00 & 0,00 & - \\
$\mathrm{Ca}$ & $\mathrm{mg} / 1$ & 0,47 & 0,44 & 1,2 \\
$\mathrm{Mg}$ & $\mathrm{mg} / 1$ & 0,09 & 0,06 & 3,24 \\
$\mathrm{Cl}$ & $\mathrm{mg} / 1$ & 0,11 & 0,11 & 6,0 \\
$\mathrm{SO}_{4}$ & $\mathrm{mg} / 1$ & 0,14 & 0,15 & 0,0 \\
$\mathrm{NO}_{3}$ & $\mathrm{mg} / 1$ & 0,03 & 0,03 & - \\
$\mathrm{HCO}_{3}$ & $\mathrm{mg} / 1$ & 0,59 & 0,55 & 20,0 \\
$\mathrm{CO}_{2}$ & $\mathrm{mg} / 1$ & 3,04 & 1,52 & - \\
& & & & \\
\hline
\end{tabular}

Sumber : 1. Sudarmadji (1995)

2. Asma Irma Setianingsih (1989)

60 
kualitas air hujan di daerah luar kota ditunjukkan pada Tabel 4.

\section{c. Air Hujan di Daerah Pantai}

Air hujan di daerah pantai sangat dipengaruhi oleh laut didekatnya. Hal ini ditunjukkan dengan kualitas yang dimiliki yang dicerminkan dengan kadar klorida, natrium dan kalium yang tinggi, yang semuanya bersumber dari air laut. Semakin jauh dari laut maka kadar zat kimia tersebut akan semakin berkurang. Beberapa sampel air hujan yang dikumpulkan dapat ditunjukkan pada tabel 5. Dari tabel tersebut bahwa daerah yang sama maka kadar klorida pada air hujan cenderung tinggi dibandingkan dengan kadar parameter yang lain.

\section{d. Air Hujan di Daerah Gunungapi}

Beberapa sampel air hujan yang didapatkan di daerah Gunungapi dapat ditunjukkan pada Tabel 5. Air hujan yang jatuh di daerah gunungapi yang masih aktif diperkirakan memiliki kadar $\mathrm{SO}_{4}$ yang tinggi, sebagai akibat aktivitas gunungapi tersebut. Hal ini memang tidak nampak secara mencolok. Namun demikian apabila dibandingkan dengan kualitas air hujan yang jatuh di daerah sekitarnya hal ini menunjukkan bahwa kadar $\mathrm{SO}_{4}$ di daerah dekat puncak gunungapi cenderung mémiliki kadar $\mathrm{SO}_{4}$ yang lebih tinggi.

\section{PEMBAHASAN}

Air hujan yang merupakan air alami yang paling mendekati air murni ternyata menunjukkan komposisi yang berbeda-beda antara satu tempat dengan tempat yang lain. Dalam air hujan tersebut telah dilarutkan berbagai zat kimia, yang kadarnya secara tidak langsung dapat diketahui dari nilai DHL dalam air hujan tersebut. Karakteristik komposisi air hujan berbeda antara daerah-daerah kota, daerah pedesaan, daerah pantai, daerah pedalaman, khususnya volkan. Perbedaan ini mungkin disebabkan oleh proses yang menyebabkan terjadinya hujan itu sendiri dan juga kadar zat kimia yang dilarutkan ketika hujan jatuh ke permukaan tanah. Daerah-daerah dekat pantai menunjukkan air hujan yang relatif tinggi akan kadar kloridanya. Kadar $\mathrm{Cl}$ yang tingi ini mencirikan juga kadar air laut. Oleh karena itu kadar tingginya kadar $\mathrm{Cl}$ pada air hujan yang jatuh didaerah pantai pasti berkaitan erat dengan air laut. Semakin jauh kedaratan maka kadar $\mathrm{Cl}$ semakin berkurang, namun daerah gunungapi kadar $\mathrm{SO}_{4}$ mendominasi kadar zat kimia dalam air hujan yang jatuh di daerah itu. Kadar $\mathrm{SO}_{4}$ yang tinggi erat kaitannya dengan gas yang di keluarkan oleh gunungapi yang aktif. Penelitian di atas juga menunjukkan kecenderungan yang sama, namun demikian arah angin tentu akan berpengaruh terhadap persebaran gas 
tersebut. Sayang beberapa penelitian belum mengungkap hal tersebut di atas.

Di daerah kota dan sekitarnya air hujan juga menunjukkan kadar zat kimia yang tinggi terutama adalah kadar $\mathrm{CO}_{2}$ dan $\mathrm{NO}_{3}$. Tingginya kadar zat kimia tersebut, khususnya $\mathrm{CO}_{2}$ nampaknya disebabkan oleh gas buang dari kendaraan bermotor. Kendaraan bermotor mengeluarkan $\mathrm{CQ}_{2}$ dan $\mathrm{CO}$ yang selanjutnya di udara bebas akan berubah menjadi $\mathrm{CO}_{2}$. Ketika hujan jatuh di daerah kota gas tersebut larut di dalam air hujan tersebut. Jauh diluar kota kadar $\mathrm{CO}_{2}$ akan berkurang dan juga ditunjukkan oleh kadar $\mathrm{CO} 2$ yang lebih rendah dalam air hujan yang jatuh di luar kota. Parameter yang lain seperti $\mathrm{Ca}, \mathrm{Mg}$, Na dan $\mathrm{K}$ masih sulit untuk diperbandingkan. $\mathrm{pH}$ air hujan tidak menunjukkan perbedaan yang mencolok, namun penelitian yang dilakukan oleh Badan Meteorologi dan Geofisika yang didapatkan dari Kantor Menteri KLH (1990), air hujan di daerah kota besar (Jakarta, Medan dan Manado) mulai menunjukkan ke cenderungan semakin menurun, dengan kata lain sudah terjadi gejala terjadinya hujan asam. Namun demikian bila dibandingkan dengan $\mathrm{pH}$ air hujan yang ditunjukkan oleh Appelo (1986), pH air hujan di Indonesia masih lebih tinggi darpada $\mathrm{pH}$ air hujan yang jatuh di kota-kota besar di negeri luar. Perbedaan waktu penelitian antara peneliti yang satu dengan peneliti yang lain sering menunjukkan perbedaan hasil yang sangat mencolok, yang menyebabkan sulitnya melakukan analisis serta interpretasi. Data lain yang dapat digunakan sangat terbatas, sehingga untuk mengatasinya seharusnya diadakan penelitian yang lebih rinci.

\section{KESIMPULAN DAN SARAN}

Beberapa hal yang dapat disimpul kan dari hasil telaah pustaka ini adalah :

1. Air hujan dibeberapa tempat, baik di pantai, di daerah volkan, di daerah pedesaan dan daerah kota telah mengandung zat kimia yang larut di dalamnya, ditunjukkan dengan nilai DHL dalam air hujan tersebut. Nilai DHL dalam air hujan tersebut bervariasi dari satu tempat ke tempat lain, dari lebih rendah $25 \mu \mathrm{mhos} / \mathrm{cm}$ hingga mendekati $100 \mu \mathrm{mhos} / \mathrm{cm}$.

2. Air hujan yang jatuh di daerah-daerah tertentu mempunyai perbedaan kualaitas yang dipengaruhi oleh kondisi daerah dimana hujan tersebut jatuh. Daerah pantai mem punyai ciri kadar $\mathrm{Cl}$ yang tinggi, sedangkan di daerah volkan dicirikan dengan kadar $\mathrm{SO}_{4}$ yang tinggi. Daerah urban dicirikan dengan kadar $\mathrm{CO}_{2}$ dan $\mathrm{NO}_{3}$ yang tinggi.

3. Kecenderungan hujan asam mulai nampak di daerah kota-kota besar, ditandai dengan rendahnya $\mathrm{pH}$ pada air hujan, namun bila dibandingkan dengan kota-kota besar di negeri luar, gejala hujan asam di Indo- 
nesia masih belum sebesar di negeri luar.

4. Perbedaan hasil penelitian yang cukup besar antara peneliti yang satu dengan peneliti yang lain menunjukkan diperlukannya penelitian yang lain untuk mendapatkan hasil yang lebih pasti. Penelitian tersebut akan sangat baik apabila dilengkapi dengan kajian tentang parameter logam berat seperti $\mathrm{Pb}$, yang merupakan salah satu yang didapatkan dalam emisi dari kendaraan bermotor.

\section{$\overline{\text { DAFTAR PUSTAKA }}$}

Appelo, T. 1986. Hydrochemistry. Lecture Note in* hydrochemistry, Caculty of Geography, Gadjah Mada University, Yogyakarta.

Bryan, E.H., 1972. Quality of stormwater Runoff Drainage from Urban Land. Water Resources Bulletin, 8: 578-588.

Carrol, D., 1962. Rainwater as A Chemical Agent of Geologic Procesces, A review Geological survey Water Supply Paper, 1535-G.

Dix, H.M., 1981. Environmental Pollution, John Wiley and Sons, New York.

Hem, J.D., 1970. Study and Intrepretation of the Chemical Characteristics of Natural Water. US. Geological Survey Water Supply Paper, No. 1473. Government Printing office, Washington DC.

Kantor Menteri KLH, 1990. Kualitas lingkungan di Indonesia 1990. Kantor Menteri KLH, Jakarta.

Setianingsih, A.A., 1989. Kualitas Air Hujan dari pantai Parangtritis sampai Puncak Gunungapi Merapi dan Faktor-faktor yang Mempengaruhinya. Skripsi Sarjana Program S1, Fakultas Geografi UGM, Yogyakarta.

Sudarmadji, 1975. Analisa Unit Kualitas Airtanah di Daerah Aliran Kali Serayu. Skripsi Sarjana Fakultas Geografi UGM, Yogyakarta.

Sudarmadji, 1995. Beberapa Aspek Hidrokimia Hutan Pinus. Majalah Geografi Indonesia No. 16 Tahun 10. September 1995. (Dalam Penerbitan). 